\title{
STANDARDIZATION AND PROXIMATE ANALYSIS OF MUSKMELON JAM
}

\author{
R. ARUNA ${ }^{1}$, K. VINAY PROMOD KUMAR ${ }^{2} \&$ P. JAYAMMA ${ }^{3}$ \\ ${ }^{1,3}$ Assistant Professor, Department of Food Safety and Quality Assurance, College of Food Science and Technology, \\ Acharya N.G. Ranga Agricultural University (ANGRAU), Chinnarangapuram, Pulivendula, Andhra Pradesh, India \\ ${ }^{2}$ Teaching Associate, Department of Food Processing Technology College of Food Science and Technology, \\ Acharya N.G. Ranga Agricultural University (ANGRAU), Chinnarangapuram, Pulivendula, Andhra Pradesh, India
}

\begin{abstract}
Most of the fruits are available in surplus during a particular season and they are perishable in nature. In off seasons, they are scarce. Even after marketing by farmers and vendors still leftover seasonal fruits are abundant to carry out the process. Unless the excess handled properly, it is economic loss to farmers and to vendors. By processing fruits, post harvest losses can be minimized and supplied in preserved form throughout the year to the growing population. Food preservation is a technique of treating and handling food to slow down food spoilage, enhance shelf life, value addition to the product Preparation of jams from seasonal fruits is one of the most popular preservation techniques. Jams have more demand because of their good taste, ready to eat form, easy to store, attractive color, easily available, nutritious and easy to manufacture and have a long shelf life.

The fruits were graded in the market based on, ripeness, shape, size The fruits were weighed, washed with tap water. Remove the peel of musk melon and cut into small pieces. From the graded musk melon extract the pulp manually by using the mixer to obtain a fine pulp. Jam is prepared and all proximate analysis is conducted.

From the present study to develop a jam from the muskmelon, four formulations with sugar, jaggery and with or without flavors were tested for sensory, physicochemical evaluation such as pH, acidity, TSS, moisture, brix/acid ratio. Two formulations 112 and 122 have high overall acceptability with score 8.2and 8.0 were tested for nutritional analysis which includes carbohydrate, protein, fat, energy, fibre, calcium and vitamin-C. The fruit pulp was taken as control and analysis was done similarly. By that we observed the variations in physicochemical parameters and nutritional composition in different formulations of prepared musk melon jam.
\end{abstract}

KEYWORDS: Musk Melon, Microbial Analysis \& Nutrition

Received: Aug 30, 2017; Accepted: Sep 20, 2017; Published: Sep 26, 2017; Paper Id.: IJASROCT201740

\section{INTRODUCTION}

Fruits are an important component of a healthy diet. They are very rich in nutritional composition. However, they are highly perishable and as a result, their post harvest losses are very high. So, processing plays important role in utilization of fruits. The most common preserved fruit products are fruit jams, jellies, squash and RTS beverage.

Most of the fruits are available in surplus during a particular season and they are perishable in nature. In off seasons, they are scarce. Even after marketing by farmers and vendors still leftover seasonal fruits are abundant to carry out the process. Unless the excess handled properly, it is economic loss to farmers and to vendors. By 
processing fruits, post harvest losses can be minimized and supplied in preserved form throughout the year to the growing population.

Food preservation is a technique of treating and handling food to slow down food spoilage, enhance shelf life, value addition to the product (Nurlina Binti Yusof., 2013) (Ref 17). Preparation of jams from seasonal fruits is one of the most popular preservation techniques. Jams have more demand because of their good taste, ready to eat form, easy to store, attractive color, easily available, nutritious and easy to manufacture and have a long shelf life.

\section{REVIEW OF LITERATURE}

C.K. Deepa et al. (2014) standardized an RTS beverage by a combination of musk melon and whey water with probiotics. Organoleptic evaluation and nutritional analysis were conducted for this product and it was concluded that incorporation of whey and probiotic can prevent our body from various disease conditions and it has good health benefits.

Desalegn Gebrezgi (2016) developed jam from fresh ripened guava. Microbial properties of this jam were analyzed. It was concluded that and reveals that jam which was prepared from guava was safe to consume for four months. This type of preservation of guava by formulating into jam increased the shelf life and extends the availability of fruit throughout the year.

Ena gupta et al. (2016) conducted studies on development of papaya gooseberry jam and evaluated sensory and nutritional parameters. These studies aimed keeping in view of the nutritional importance of papaya and gooseberry and prolonging their lifespan by preserving them in the form of jam and conducting analysis for organoleptic acceptability. He concluded that incorporating gooseberry pulp in papaya jam improved its quality and has good impact on nutritional components like fiber, calcium, vitamin $\mathrm{C}$ and phosphorus and antioxidant activity.

Helen O. Okudu et al. (2015) evaluated the effect of storage time and temperature on physicochemical characteristics of jam developed from monkey kola. This study aimed at evaluating physicochemical properties like $\mathrm{pH}$, TSS, titratable acidity in relation to storage time. The parameters were analyzed in refrigeration and room temperature conditions. It was concluded that it has a longer shelf life when stored in refrigerator.

Iftikhar shakir et al. (2007) carried out studies in preparation of mixed fruit jam with different ratios. All these jams samples are stored and different parameters like ascorbic acid, acidity, pH, TSS, reducing sugars and non reducing sugars are evaluated physicochemical at intervals. These studies finally concluded that a decrease in ascorbic acid content was observed during storage.

Imen Henan et al. (2013) investigated quality parameters of musk melon like carotenoids and phenolic content. He concluded that orange fleshed musk melon contained highest value of carotenoids and phenolic content.

John Saka et al. (2007) conducted studies in preparation of juices and jams from different fruits. Trained tenmember panel members evaluated and analyzed physicochemical and shelf life characteristics of these products. These studies indicated that these products are a rich source of zinc, copper and phosphorus.

M.A. Augustin et al. Studied physicochemical changes in musk melons. The evaluation of physicochemical characteristics like $\mathrm{pH}$, Titratable acid, ascorbic acid content was done during storage. This evaluation represents shelf life of fruits during storage. 
M.N. Mohd Naeem et al. (2017) conducted studies on the nutritional evaluation of four commonly consumed fruit jams that are available in the Malaysian market. Fruit jams have very low level of fatty acids. This study concluded that fruit jams provide a good source of energy and carbohydrates.

Marjan Javanmard et al. (2010) studied rheological properties of jam and factors influencing quality of the jam. Color content, taste, flavor and texture influence the quality of the jam. Rheological behavior of jam was studied and it was concluded that temperature governs the rheological behavior of jam. The difference in rheological properties occurs as the temperature is increased.

\section{MATERIALS AND METHODS}

\section{Procurement of Raw Materials}

The raw materials, namely musk melon, sugar, jaggery, flavor, citric acid, etc., was procured from the local market of Pulivendula.

\section{Fruit Selection}

Fresh, ripen Musk melon fruits were purchased from local markets to prepare jam.

\section{Fruit Preparation}

The fruits were graded in the market based on, ripeness, shape, size (Ena Gupta et al, 2016). The fruits were weighed, washed with tap water. Remove the peel of musk melon and cut into small pieces. From the graded musk melon extract the pulp manually by using the mixer to obtain a fine pulp.

\section{Equipment for Preparation of Jam}

- Weighing machine

- Knives

- $\quad$ Mixer

- $\quad$ Stainless steel bowls

- Laddles and spoons

- $\quad$ Glass jars

\section{Equipment Involved in Analysis of Jam}

- $\quad$ Refract Meter: It is used for determination of total soluble solids (58-90 $0^{\circ}$ brix).

- $\quad$ pH Meter: It is used to measure $\mathrm{pH}$ of samples.

- Hot Air Oven: It is used for estimation of moisture content

- Colorimeter: It is used in the measurement of optical density values.

- Muffle Furnace: It is used for estimation of crude fiber and determination of ash.

- Hunter lab colorimeter: It is used for determine color of sample. 
- Water bath

- Weighing machine

- Petri dishes

- $\quad$ Pipettes

- $\quad$ Burettes

- $\quad$ Test tubes

- Volumetric flask

- $\quad$ Measuring cylinders

\section{Preparation of Musk Melon Jam}

Control

Pulp of musk melon treated as control for analysis of physicochemical and nutritive values.

\section{Sample 111}

In the sample 111, musk melon jam was prepared by using sugar.

\section{Sample 112}

In the sample 112, musk melon jam was prepared by using sugar and flavor.

\section{Sample 121}

In the sample 121, musk melon jam was prepared by using jaggery.

\section{Sample 122}

In the sample 122, musk melon jam was prepared by using jaggery and flavor.

Source- Sri lakshmi. B (Food science, 2011)(Ref 26).

Table 1: Formulation of Ingredients in Musk Melon Jam

\begin{tabular}{|l|c|c|c|c|}
\hline \multirow{2}{*}{ Ingredients } & Sample 111 & Sample 112 & Sample 121 & Sample 122 \\
\cline { 2 - 5 } & Sugar & Sugar and Flavor & Jaggery & Jaggery and Flavour \\
\hline Musk melon pulp & $500 \mathrm{gm}$ & $500 \mathrm{gm}$ & $500 \mathrm{gm}$ & $500 \mathrm{gm}$ \\
\hline Sugar & $375 \mathrm{gm}$ & $375 \mathrm{gm}$ & - & - \\
\hline Jaggery & - & - & $375 \mathrm{gm}$ & $375 \mathrm{gm}$ \\
\hline Citric acid & $1.25 \mathrm{gm}$ & $1.25 \mathrm{gm}$ & $1.25 \mathrm{gm}$ & $1.25 \mathrm{gm}$ \\
\hline Flavor & - & $3-4$ drops & - & $3-4$ drops \\
\hline
\end{tabular}

Reference: Fruits and vegetable preservation (R. P. Srivastava, 2011) (Ref 19) 
Flow Chart for Preparation of Jam

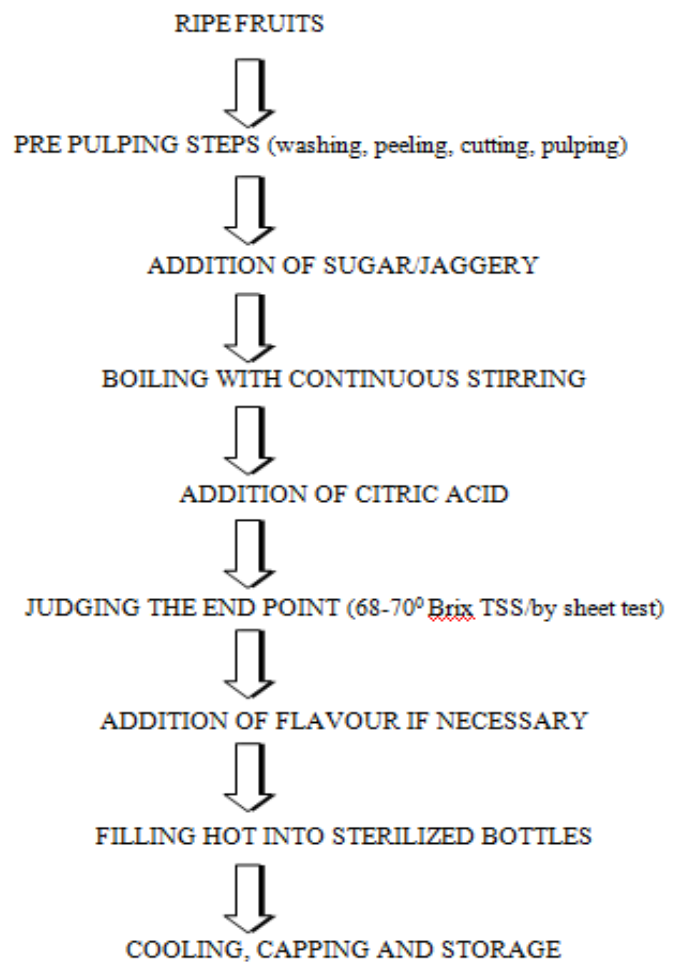

Figure 1

Source: Fruit and vegetable preservation (R. P. Srivastava, 2011) (Ref 19).

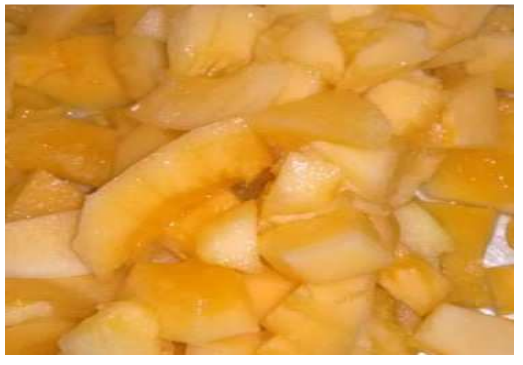

Fruit Pieces

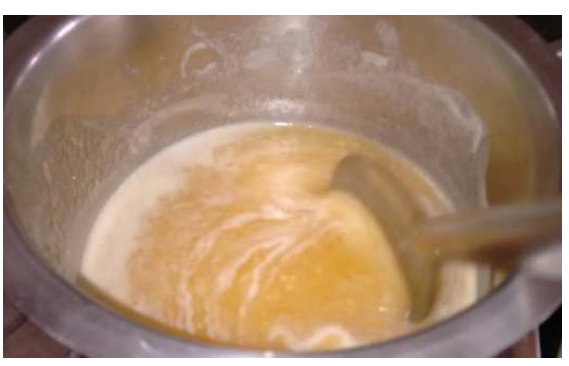

Boiling

Figure 2

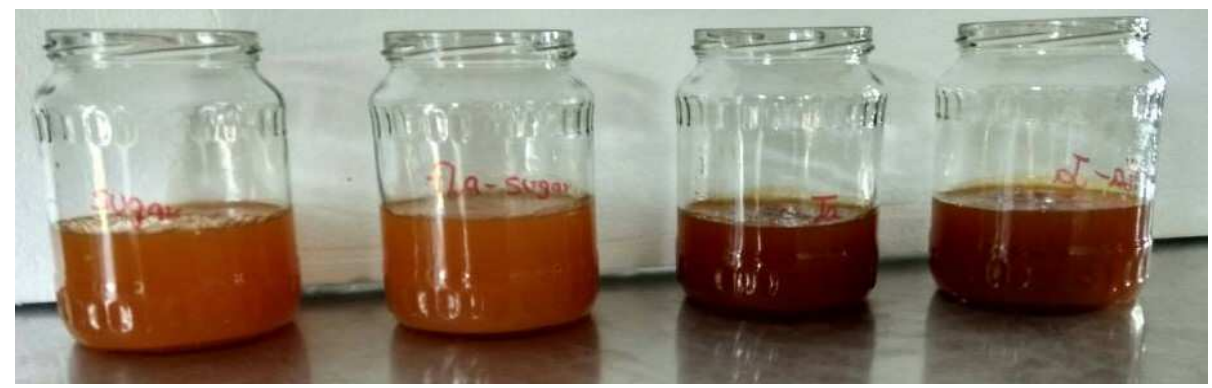

Sample111

Sample112

Sample121

Sample122

Figure 3 


\section{RESULTS AND DISCUSSIONS}

The study was undertaken to develop musk melon jam and to analyze its parameters.

Results of the study are discussed as under:

Organoleptic evaluation

Table 2: Sensory Evaluation of Musk Melon Jam

\begin{tabular}{|c|l|c|c|c|c|}
\hline S. No & \multicolumn{1}{|c|}{ Criteria } & Sample 111 & Sample 112 & Sample 121 & Sample 122 \\
\hline 1. & Taste & $7.7 \pm 0.45$ & $8.2 \pm 0.87$ & $7.9 \pm 0.94$ & $8.3 \pm 0.78$ \\
\hline 2. & Texture & $7.1 \pm 0.83$ & $7.9 \pm 0.70$ & $7.6 \pm 0.91$ & $7.4 \pm 0.80$ \\
\hline 3. & Flavor & $7.0 \pm 0.63$ & $7.6 \pm 0.48$ & $7.8 \pm 0.60$ & $7.7 \pm 0.64$ \\
\hline 4. & Appearance & $7.8 \pm 0.87$ & $8.3 \pm 0.78$ & $8.1 \pm 0.83$ & $8.3 \pm 0.64$ \\
\hline 5. & Overall acceptability & $7.5 \pm 0.67$ & $8.2 \pm 0.87$ & $7.8 \pm 0.60$ & $8.0 \pm 0.63$ \\
\hline
\end{tabular}

Taste

The score for taste was found highest in sample 122(jaggery with mixed fruit flavor).

\section{Texture}

The score for texture was found highest in sample 112(sugar with mixed fruit flavor).

Flavor

The score for flavor was found highest in sample 121(jaggery).

\section{Appearance}

The score for appearance was found highest in sample 112 (sugar with flavor) and sample 122 (jaggery with mixed fruit flavor).

\section{Overall Acceptability}

The score for the overall acceptability was found highest $(8.2 \pm 0.87)$ in the sample 112 (sugar with mixed fruit flavor) followed by sample 122 (Jaggery and flavor) with the overall acceptability of (8.0 \pm 0.6$)$

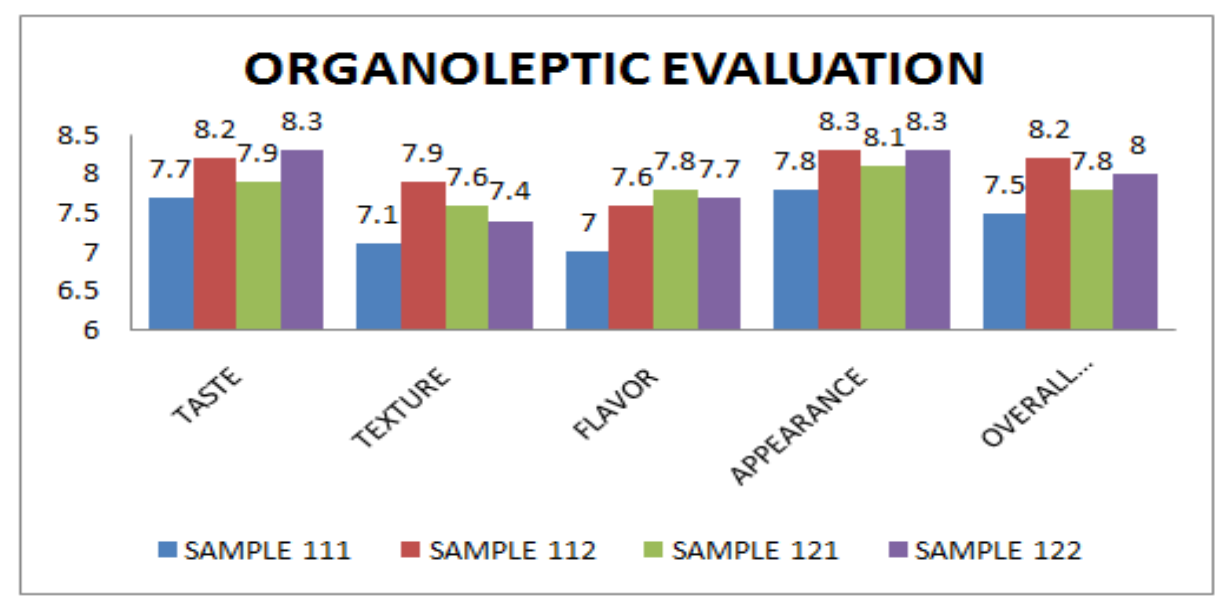

Figure 4: Organoleptic Evaluation of Musk Melon Jam 


\section{PHYSICOCHEMICAL ANALYSIS}

The Results of Physicochemical Analysis are Illustrated Below

Table 3: Physicochemical Parameters of Musk Melon Jam

\begin{tabular}{|c|l|c|c|c|c|c|}
\hline S. No & Parameter & Control & Sample 111 & Sample 112 & Sample 121 & Sample 122 \\
\hline 1 & pH & $5.67 \pm 0.02$ & $5.45 \pm 0.02$ & $5.46 \pm 0.01$ & $5.02 \pm 0.01$ & $5.02 \pm 0.01$ \\
\hline 2 & Acidity & $0.14 \pm 0.07$ & $0.33 \pm 0.07$ & $0.32 \pm 0.02$ & $0.42 \pm 0.05$ & $0.42 \pm 0.05$ \\
\hline 3 & TSS & $7 \pm 0.01$ & $68 \pm 0.02$ & $68 \pm 0.02$ & $68 \pm 0.02$ & $68 \pm 0.02$ \\
\hline 4 & Moisture & $88.25 \pm 0.14$ & $30.55 \pm 0.03$ & $30.50 \pm 0.02$ & $35.85 \pm 0.01$ & $35.75 \pm 0.01$ \\
\hline 5 & Brix/acid ratio & $47.61 \pm 0.12$ & $206.06 \pm 0.27$ & $212.36 \pm 0.10$ & $161.90 \pm 0.21$ & $161.90 \pm 0.21$ \\
\hline
\end{tabular}

\section{Moisture Content}

The results of moisture analysis have been presented in table. On observations of the data, it was indicated that the moisture content of the control (pulp), sample 111, sample112, sample 121, sample 122 of jam were 88.25\%, 30.55\%, $30.50 \%, 35.85 \%, 35.75 \%$ respectively. From the above observation sample 121 and sample 122 has higher moisture content than sample 111, sample 112 and control (pulp) has very high moisture content.

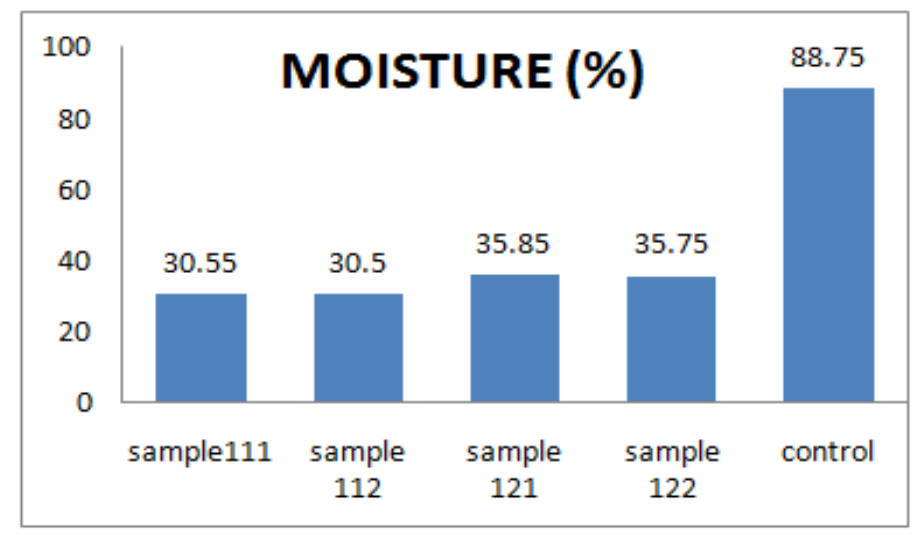

Figure 5: Variation of Moisture Content in Musk Melon Jam

pH

The $\mathrm{pH}$ values of the various samples are presented in the table. $\mathrm{pH}$ of the control, sample 111, sample 112, sample 121, sample 122 of jam were 5.7, 5.45, 5.02, 5.02 respectively. When compare to control (pulp) samples are more acidic. By comparing between jam with jaggery and sugar, jam with sugar is less acidic than jaggery.

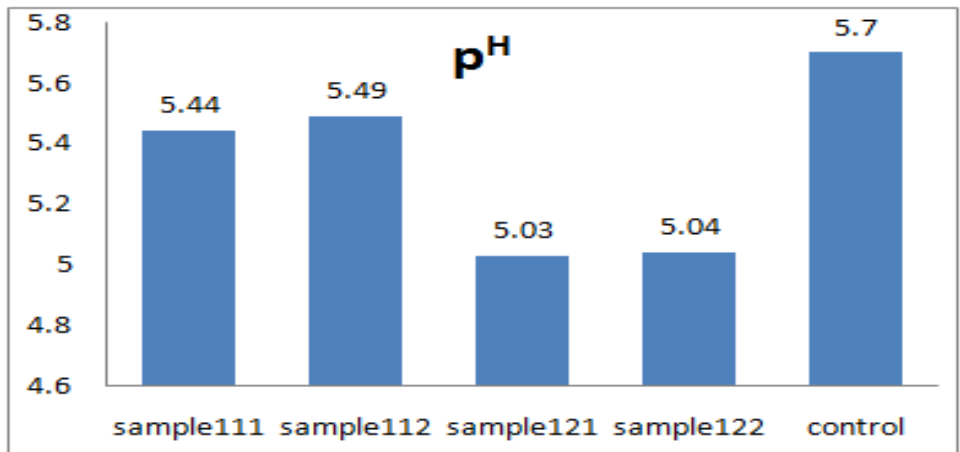

Figure 6: Variation of pH in Musk Melon Jam 
TSS

The total soluble solids determined are presented in the table. TSS of the control, sample 111, sample 112, sample 121, sample 122 of jam was 7, 68, 68, 68, and 68 respectively. The total soluble solids of samples are shown similarly compare to control (pulp).

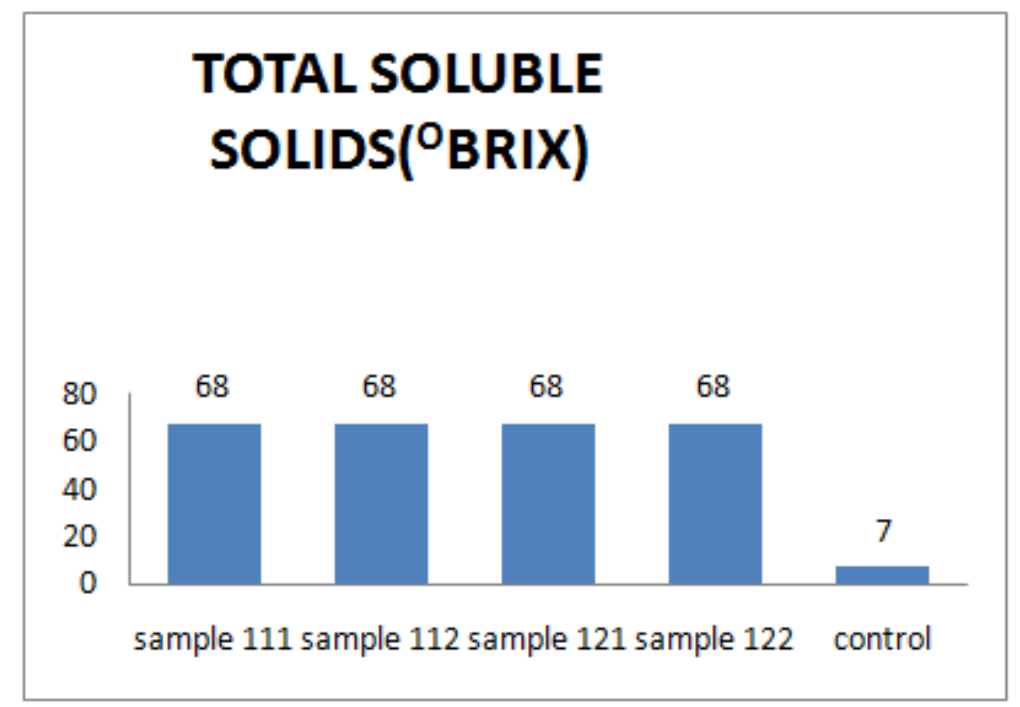

Figure 7: Variation in TSS of Musk Melon Jam

Acidity

The acidity of jam is expressed in terms of percent of citric acid present in the sample. The acidity determined for the samples is listed in the table. Acidity of control, sample 111, sample 112, sample 121, and sample 122 of jam were $0.14,0.33,0.32,0.42$, and 0.42 respectively.

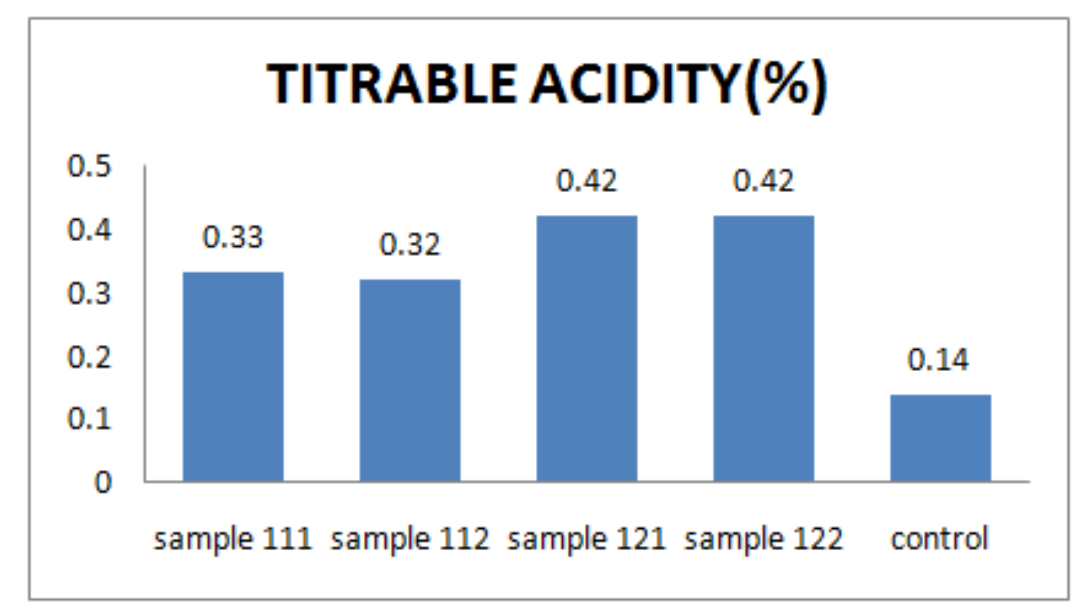

Figure 8: Variation of Acidity in Musk Melon Jam

\section{Brix/ Acid Ratio}

This value indicates the sweetness of the product with respect to acidity. Higher the ratio sweeter is the product. These values are represented in the table. The Brix / acid ratio for control, sample 111, sample 112, sample 121, sample 
122 of jam was 206.06, 212.36, 161.90, 161.90, and 47.61 respectively. We observed that all except control are having same Brix/ acid ratio, hence we can say that they are sweeter than control.

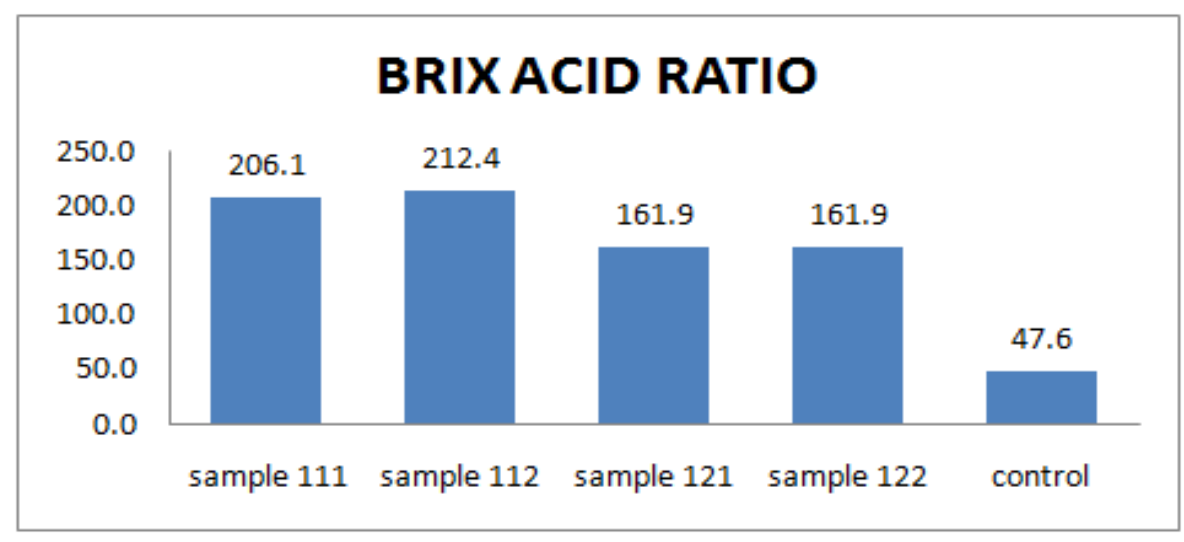

Figure 9: Variation of Brix/ Acid Ratio in Musk Melon Jam

\section{NUTRITIONAL ANALYSIS}

The nutrient content of musk melon jam was illustrated below for sample 112 and sample 122 with control due to its high overall acceptability compared to sample111, sample 121 in sensory evaluation.

Table 4: Nutrient Content of Musk Melon Jam

\begin{tabular}{|c|l|c|c|c|}
\hline S. No & Parameter & Control & Sample 112 & Sample114 \\
\hline 1 & Protein & $1.0 \pm 0.01$ & $0.72 \pm 0.02$ & $0.86 \pm 0.05$ \\
\hline 2 & Carbohydrate & $41 \pm 0.5$ & $54 \pm 0.5$ & $52 \pm 1.1$ \\
\hline 3 & Fat & $0.86 \pm 0.01$ & $0.25 \pm 0.01$ & $0.24 \pm 0.02$ \\
\hline 4 & Energy & $213.60 \pm 0.07$ & $175.76 \pm 0.07$ & $221.19 \pm 0.07$ \\
\hline 5 & Fibre & $0.74 \pm 0.03$ & $0.48 \pm 0.03$ & $0.67 \pm 0.01$ \\
\hline 6 & Calcium & $10.92 \pm 0.03$ & $10.52 \pm 0.07$ & $10.64 \pm 0.07$ \\
\hline 7 & Vitamin-C & $42.5 \pm 0.3$ & $32.50 \pm 0.31$ & $30 \pm 0.2$ \\
\hline
\end{tabular}

\section{Energy}

The results of energy present in control, sample 112, sample 122 of jam were 175.76 K Cal, 213.60 Kcal, 221.19 Kcal. From the above values we can conclude that sample 122 has more energy compared to sample 112 and control.

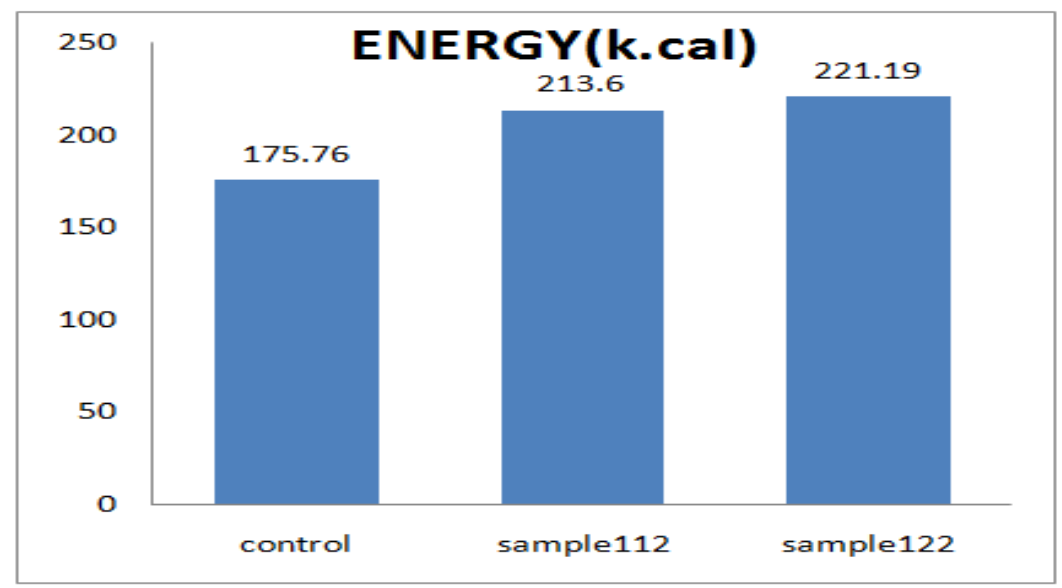

Figure 10: Variation of Energy in Musk Melon Jam 


\section{Carbohydrates}

The results of carbohydrates done by anthrone method present in control, sample 112, sample 122 of jam were $41 \mathrm{~g}, 52 \mathrm{~g}, 54 \mathrm{~g}$ respectively. From the above observation, we can conclude that control has less carbohydrate than samples made with sugar and jaggery.

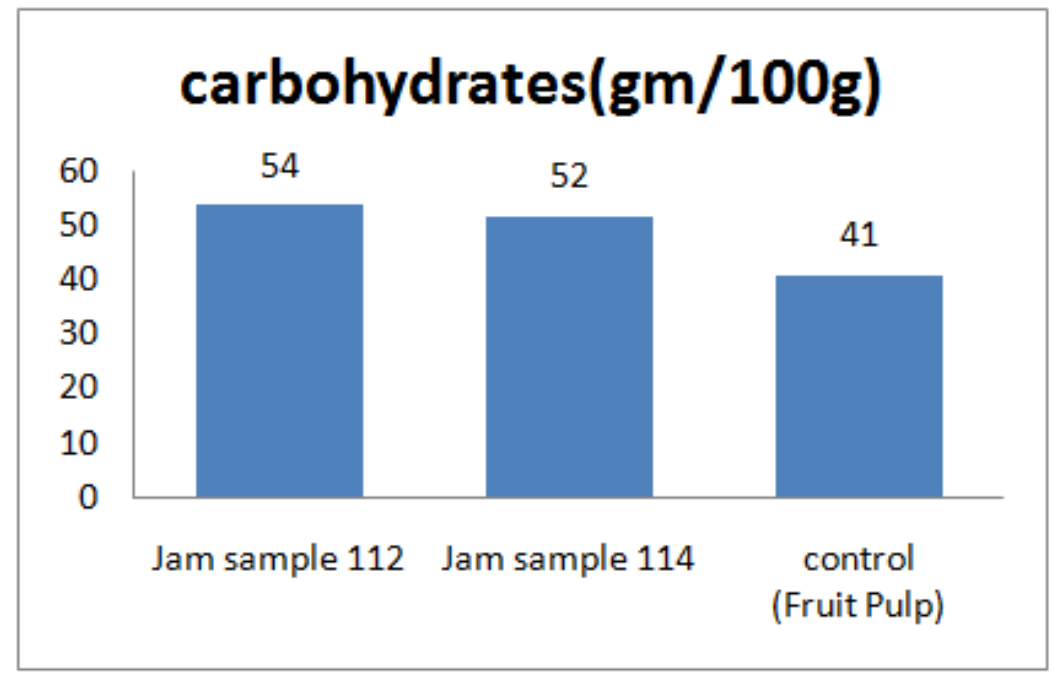

Figure 11: Variation in Carbohydrates in Musk Melon Jam

\section{Protein}

The results of musk melon jam of control, sample 112 , sample 122 , and control were $0.72 \mathrm{~g}, 0.86 \mathrm{~g}$, and $1 \mathrm{~g}$. By that we concluded that control has higher protein content than the jam of musk melon.

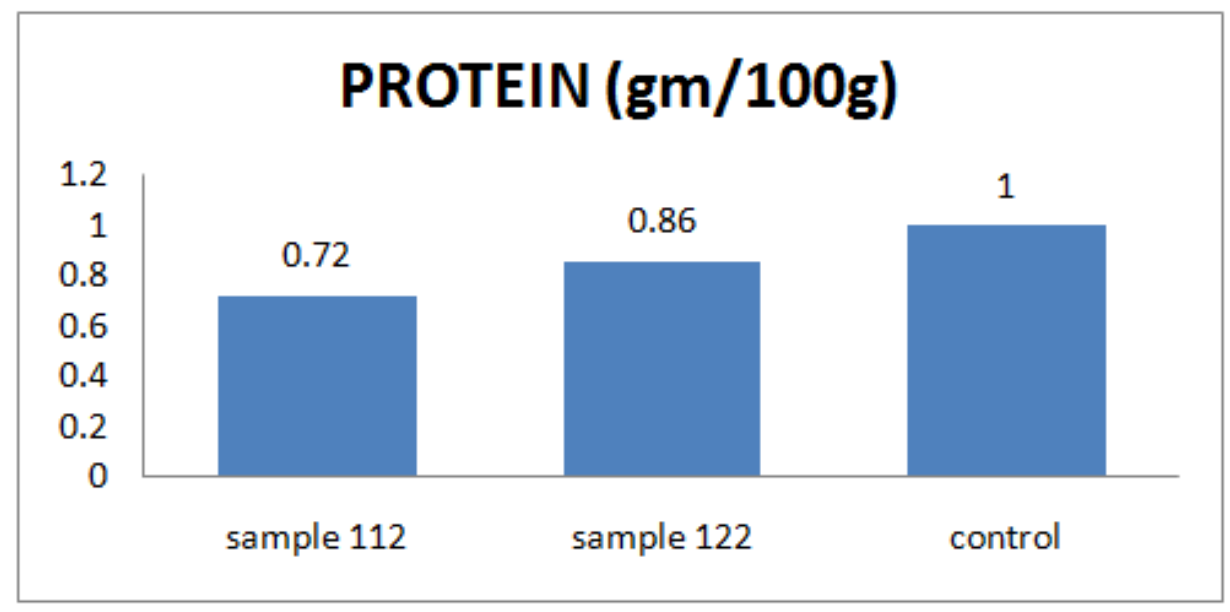

Figure 12: Variation of Protein Content in Musk Melon Jam

Fat

The fat content of musk melon jam and pulp was noted here. The results of sample 112, sample 122, and control were $0.25 \mathrm{gm}, 0.24 \mathrm{gm}, 0.86 \mathrm{gm}$ respectively. The percent of fat in control is more compared to samples. 


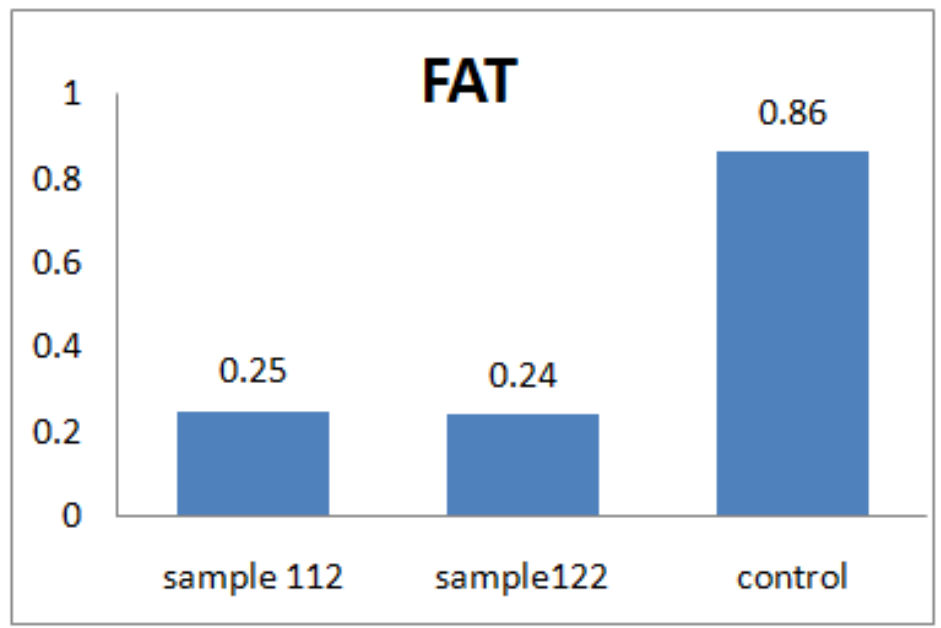

Figure 13: Variation of Fat in Musk Melon Jam

\section{Ascorbic Acid}

The ascorbic acid of musk melon jam of sample 112, sample 122 and control were $32.50 \mathrm{mg}, 30 \mathrm{mg}, 42.50 \mathrm{mg}$ respectively. By that we observed that control has high ascorbic acid compare to muskmelon jam.

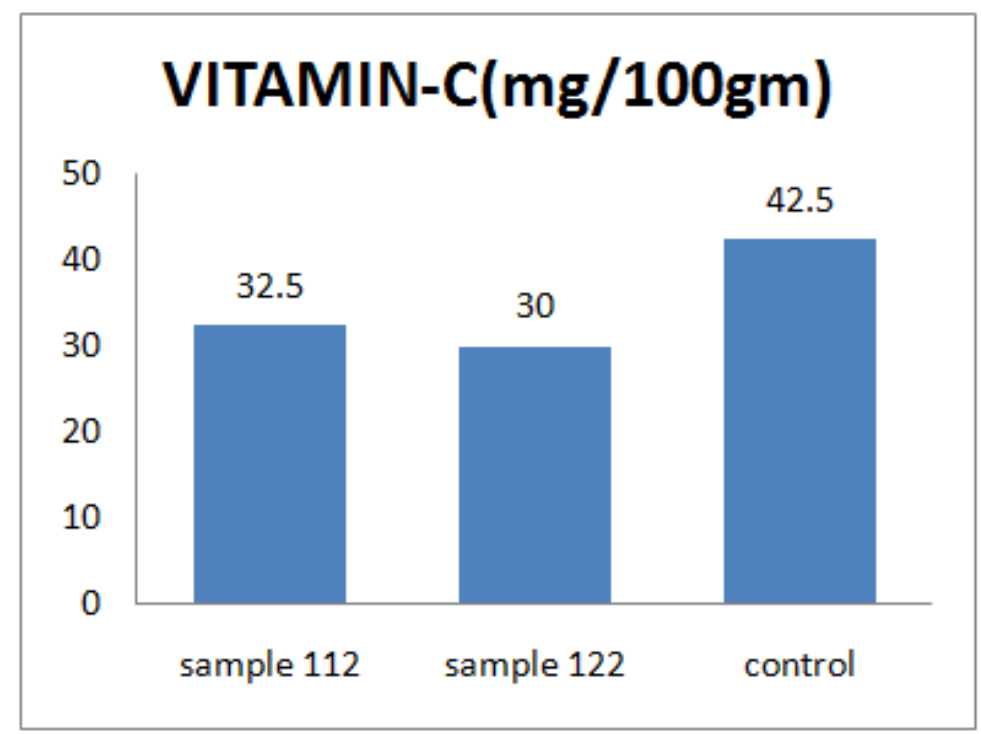

Figure 14: Variation of Ascorbic acid in Musk Melon Jam

\section{Crude Fibre}

The values of sample 112 and sample 122 are respectively $0.48 \%$ and $0.67 \%$ respectively and less when compared to control value which is $0.74 \%$. 


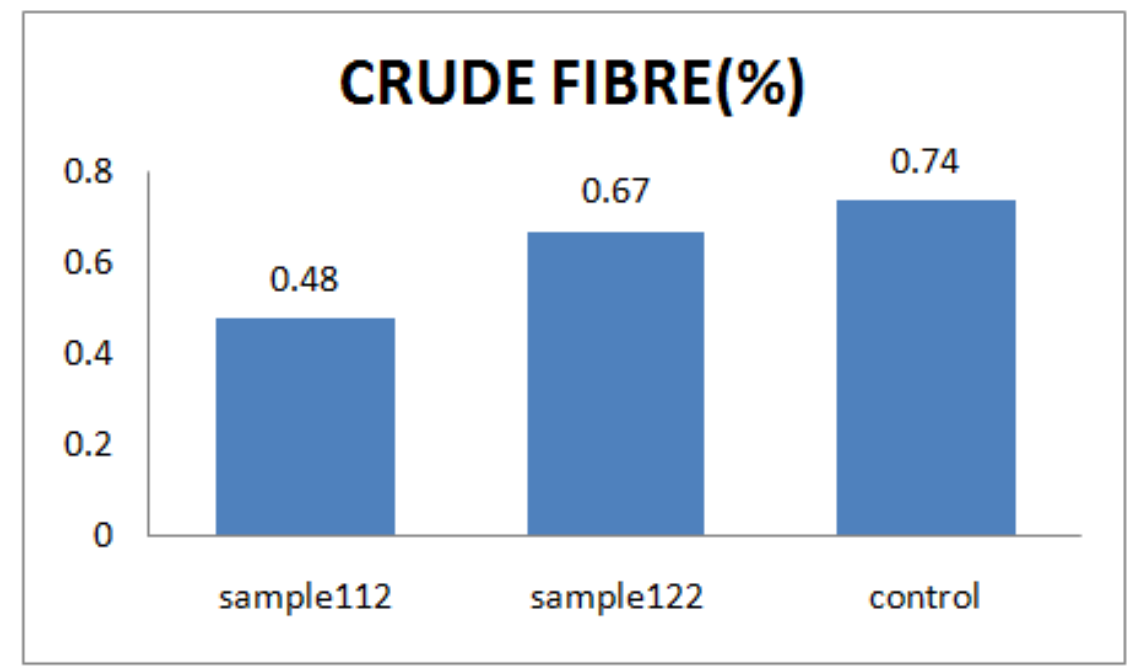

Figure 15: Variation of Crude Fibre in Musk Melon Jam

Ash

The results of percent ash in muskmelon jam present in control, sample 112, sample 122 of jam were $0.31 \%$, $0.31 \%, 0.31 \%$ respectively. From the above observation, we can conclude that control as a less percentage of ash compare to samples.

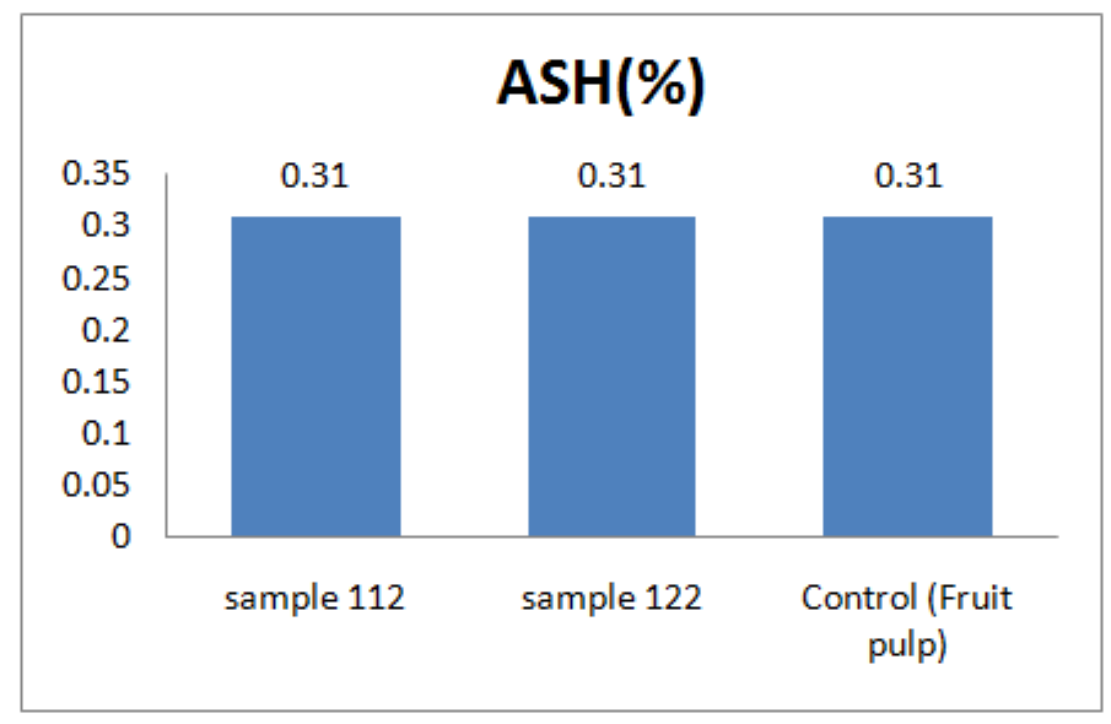

Figure 16: Variation in Ash in Musk Melon Jam

\section{Calcium}

The results of calcium in $\mathrm{mg}$ were calculated. The results obtained for sample112, sample 122 , control were $10.52 \mathrm{mg}, 10.64 \mathrm{mg}$ and $10.92 \mathrm{mg}$ respectively. We observe that pulp has high calcium content. 


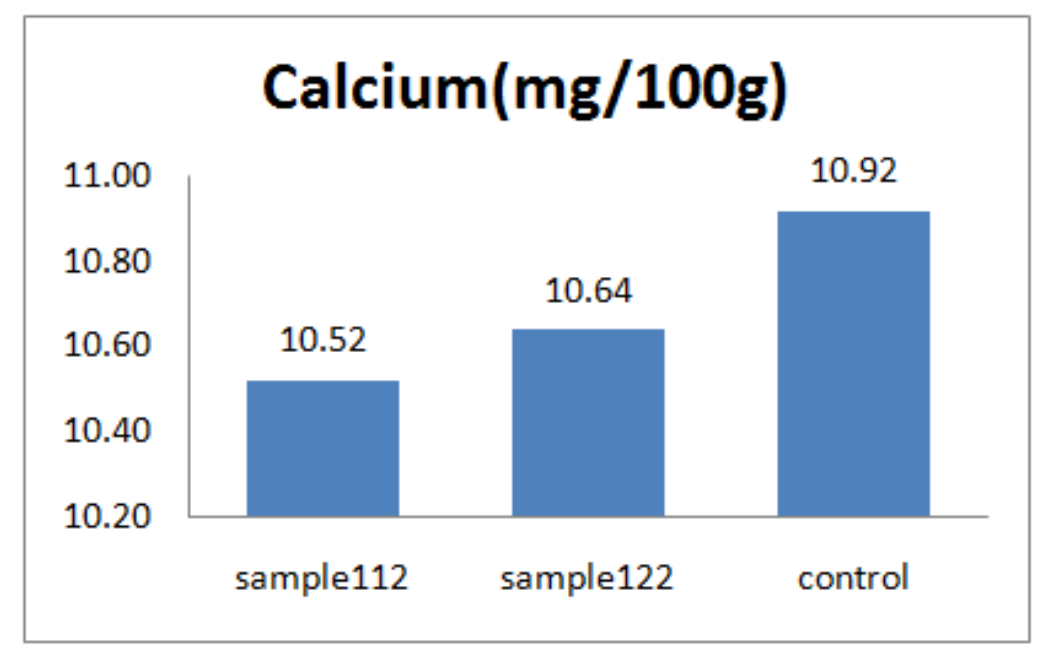

Figure 17: Variation of Calcium in Musk Melon Jam

\section{Reducing Sugars}

The content of reducing sugars in sample112 and sample122 and control is approximately 5\%, 8\%, 3\%. The reducing sugars are high in samples of jams compared to control.

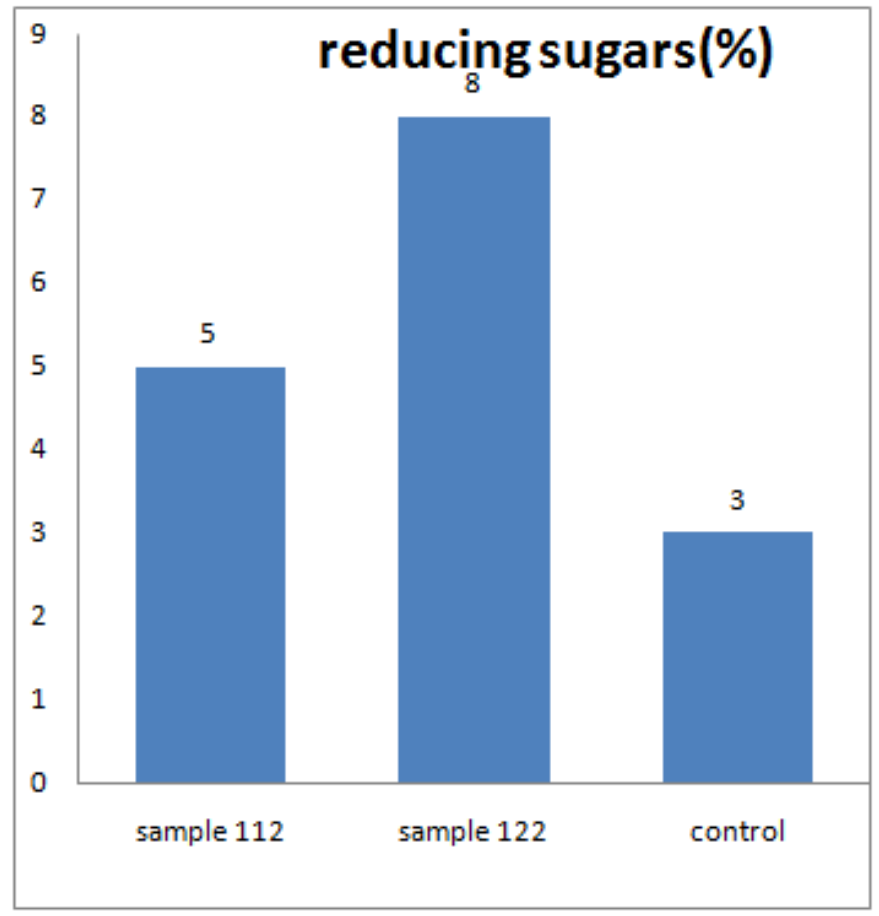

Figure 18: Variation of Reducing Sugars in Musk Melon Jam

\section{MICROBIAL ANALYSIS}

Determination of Microbial load in the samples stored both at room temperature and refrigerated conditions. Bacterial load was observed in pulp stored at room temperature, whereas refrigerated samples (jam, pulp) shown no bacterial count. Fungal count was not reported in all the samples. 
Table 5: Microbial Load of Musk Melon Jam

\begin{tabular}{|c|c|c|c|c|c|c|c|}
\hline \multirow[t]{2}{*}{ Group } & \multirow[t]{2}{*}{ Dilution } & \multicolumn{2}{|c|}{ Control } & \multicolumn{2}{|c|}{ Sample112 } & \multicolumn{2}{|c|}{ Sample122 } \\
\hline & & $\begin{array}{c}\text { Room } \\
\text { Temperature }\end{array}$ & Refrigeration & $\begin{array}{c}\text { Room } \\
\text { Temperature }\end{array}$ & Refrigeration & $\begin{array}{c}\text { Room } \\
\text { Temperature }\end{array}$ & Refrigeration \\
\hline \multirow{5}{*}{$\begin{array}{l}\text { Bacterial } \\
\text { count }\end{array}$} & $10^{-1}$ & $8 * 10^{3}$ & Nil & Nil & Nil & Nil & Nil \\
\hline & $10^{-2}$ & $7 * 10^{4}$ & Nil & Nil & Nil & Nil & Nil \\
\hline & $10^{-3}$ & $5 * 10^{5}$ & Nil & Nil & Nil & Nil & Nil \\
\hline & $10^{-4}$ & $3 * 10^{6}$ & Nil & Nil & Nil & Nil & Nil \\
\hline & $10^{-5}$ & $2 * 10^{7}$ & Nil & Nil & Nil & Nil & Nil \\
\hline \multirow{5}{*}{$\begin{array}{l}\text { Fungal } \\
\text { count }\end{array}$} & $10^{-1}$ & Nil & Nil & Nil & Nil & Nil & Nil \\
\hline & $10^{-2}$ & Nil & Nil & Nil & Nil & Nil & Nil \\
\hline & $10^{-3}$ & Nil & Nil & Nil & Nil & Nil & Nil \\
\hline & $10^{-4}$ & Nil & Nil & Nil & Nil & Nil & Nil \\
\hline & $10^{-5}$ & Nil & Nil & Nil & Nil & Nil & Nil \\
\hline
\end{tabular}

\section{CONCLUSIONS}

In the present study to develop a Jam from the muskmelon, four formulations with sugar, jaggery and with or without flavors were tested for sensory, physicochemical evaluation such as pH, acidity, TSS, moisture, Brix/acid ratio. Two formulations 112 and 122 have high overall acceptability with score 8.2and 8.0 were tested for nutritional analysis which includes carbohydrate, protein, fat, energy, fibre, calcium and vitamin-C. The fruit pulp was taken as control and analysis was done similarly. By that we observed the variations in physicochemical parameters and nutritional composition in different formulations of prepared musk melon jam.

\section{REFERENCES}

1. D. Ghanbarian1, Z. A. Shojaeil,A.Ebrahimiland S.Yunejil, "Physical Properties and Compositional Changes of two Cultivars of Cantaloupe Fruit During Various Maturity Stages”, Iran Agricultural Research, Vol. 25, No. 2 and Vol. 26, No. $1-2$.

2. Desalegn, Gebrezgi, Mekelle agri, "Developing and Evaluating Techniques of Guava Jam Processing”, Cultural mechanization and rural energy research center, Department of postharvest technology, Food Science and Quality Management www.iiste.orgISSN 2224-6088 (Paper) ISSN 2225-0557 (Online) Vol. 49, 2016.

3. Deepa C.K and V. Krishnaprabha, "Development and nutrient, ant oxidant and microbial analysis of Muskmelon and whey water and probiotics incorporated squash”, International journal of current Microbiology and applied sciences (2014) 3(5),267-271. (NAAS rating)

4. Ena Gupta1, Shalini Purwar1, Pragati Jaiswal2, Reena Chaturvedi2, G. K. Rai2, "Sensory Evaluation and Nutritional Composition of Developed Papaya-Gooseberry Jam”,Food and Nutrition Sciences, 2016, 7, 600-608.

5. Helen O. Okudu 2Henrietta N. Ene-Obong, "Evaluation of the effect of storage time and temperature on some physicochemical properties of juice and jam developed from two varieties of monkey kola (Cola parchycarpa, Cola lepidota)", African Journal of Food Science and Technology (ISSN: 2141-5455) Vol. 6(7) pp. 194-203, November, 2015.

6. Iftikhar Shakir, Imtiaz Hussain, 12 3Alam Zeb and 3Yasser Durrani, "Sensory Evaluation and Microbial Analysis of Apple and Pear Mixed Fruit Jam Prepared from Varieties Grown in Azad Jammu and KashmirWorld”, Journal of Dairy \& Food Sciences 4 (2): 201-204, 2009.

7. Iftikhar Shakir, Yasser Durrani, Imtiaz Hussainm, Ihsan Mabood Qazi and Alam Zeb. "Physicochemical Analysis of Apple and Pear Mixed Fruit Jam Prepared from Varieties Grown in Azad Jammu and Kashir”, international Journal of Food Safety, Vol.9, 2007, p. 22-24.(NAAS rating)

8. Imen Henan, Imen Tlili, Riadh Ilahy, Thouraya $R$ ' him, Hager Jebari, "Evaluation of qualitative parameters and 
physicochemical properties of local varieties of Muskmelon gron in Tunisia”, global science books.

9. John Saka,1* Isabel Rapp,2 Festus Akinnifesi,3 Victoria Ndolo4 \& Jarrett mhango, "Physicochemical and organoleptic characteristics of Uapaca kirkiana, Strychnos cocculoides, Adansonia digitata and Mangifera indica fruit products", International Journal of Food Science and Technology 2007, 42, 836-84.

10. Kambham Venkateswarlu, N.Devann, R.Venu Priya, P.Bharath Rathna Kumar, "MUSK MELON: MINERALS, NUTRITIONAL VALUES", pharmatutor journal.

11. M. Branca SILVA, Susana CASAL, Paula B.ANDRADE, Rosa M. SEABRA, M.Beatriz OLIVERIA and Margarida A. FERREIRA, "Development and evaluation of a GC/FID Method for the analysis of free amino acids in quince fruit and jam", ANALYTICAL SCIENCES SEPTEMBER 2003 ,VOL.19.

12. M.N. Mohd Naeem, M.N. Mohd Fairulnizal, M.K.Norhayati, A.Zaiton, A.H. Norliza, W.Z. Wan Syuriahti, J.Mohd Azerulazree, A.R. Aswir, S.Rusidah, "The nutritional composition of fruit jams in the Malaysian market”, Journal of the Saudi Society of Agricultural sciences(2017) 16, 89-96.

13. Manika Mehra, Vani Pasricha, Rajinder k gupta, "Estimation of nutritional, phytochemical and antioxidant activity of seeds of musk melon (Cucumis melo) and water melon (Citrullus lanatus) and nutritional analysis of their respective oils", journal of pharmacognosy and phytochemistry2015;3(6);98-102.(NAAS rating)

14. Marjan Javanmard and Johari Endan “A Survey on Rheological Properties of Fruit Jams”, International Journal of Chemical Engineering and Applications, Vol. 1, No. 1, June 2010.

15. Menon, S. V. and *Ramana Rao, T. V. B. R. Doshi, "Nutritional quality of muskmelon fruit as revealed by its biochemical properties during different rates of ripening” International Food Research Journal 19(4): 1621-1628 (2012).

16. Ndabikunze B. K,Masambu B.N, Tiisekwa B.P.M. and Issa-Zacharia A. “ The production of jam from indigenous fruits using baobab (Adansonia digitata L.) powder as a substitute for commercial pectin”, African Journal of Food Science vol. 5(3)pp. 168-175, march 2011.

17. Nurlina Binti Yusuf, "optimization of process conditions for production of jam from honey dew skin" International Islamic university, Malaysia(2013).

18. Parle milind and singhi kulwant, “musk melon is eat-must melon”, international research journal of pharmacy,irjp 2(8) 2011 52-57.

19. R.P. Srivastava, Sanjeev Kumar "Fruit and Vegetable preservation-Principles and practices" $3^{\text {rd }}$ edition, IBDC publishers.

20. Rafeek M. Abolila, Hassan Barakat*, Hassan A. El-Tanahy, Hamdy A. El-Mansy, "Chemical, Nutritional and Organoleptical Characteristics of Orange-Based Formulated Low-Calorie Jams”, Food and Nutrition Sciences, 2015, 6, 1229-1244.(NAAS rating)

21. Roopa.N, Das Gupta DK, *Radhika M, “storage stability of restructured muskmelon gel preserved by hurdle technology" journal of food science and technology, 2008,45(5).430(4).

22. S. Suzanne Nielsen "Food Analysis", 3rd edition, CBS Publishers.

23. S.K. Thimmaiah "Standard methods of biochemical analysis", Kalyani Publishers.

24. S.Sadasivan, A.Manickan "Bio chemical methods" $3^{\text {rd }}$ edition, New age international(P) Ltd, publishers. 
25. Souad Abati Mohamad, *Olorunnisola Kola Saheed and Parveen Jamal, "Physicochemical Analysis of Jam Preparations from Watermelon Waste”, International Conference on Chemical, Environmental and Biological Sciences (ICCEBS'2012) Penang, Malaysia.

26. Srilakshmi.B, "Food science", sixth edition pp (308-331), New age international( $P$ ) Ltd, publishers.

27. T.Ahmed, *M.burhanuddin, M.A.Haque, M.A.Hossain, "Preperaton of jam from Sapota(Achras zapota)", A Scientfic journal of Krishi Foudation, The Agriculturists 9(1and2), 1-7(2011).

28. Tariq Kamal1 *, Sana Khan2, Muhammad Riaz3 and Mehnaz Safdar, "Functional Properties and Preparation of Diet Apricot jam”, Journal of Food Process Technology 2015, 6:8. 